\title{
Some outcomes of the Nomenclature Section of the XIXth International Botanical Congress
}

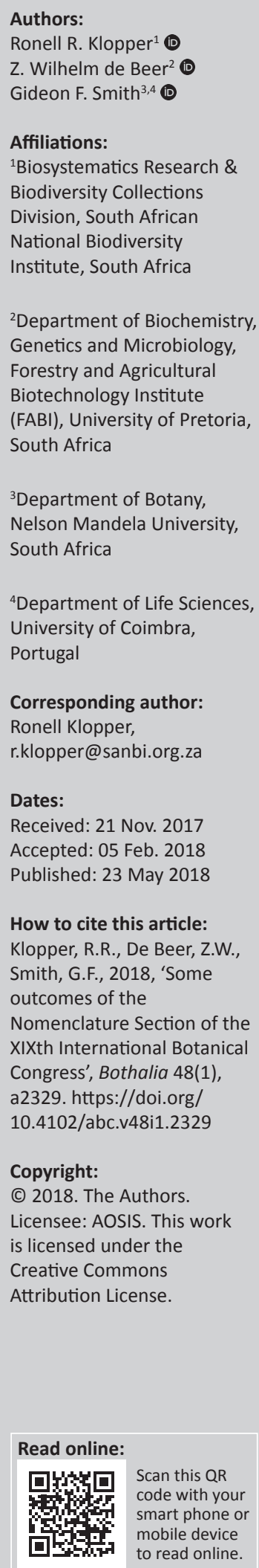

Background: A Nomenclature Section meeting to amend the International Code of Nomenclature for algae, fungi and plants is held every six years, a week before the International Botanical Congress.

Objectives: To report on some of the outcomes of the Nomenclature Section of the XIXth International Botanical Congress that was held in Shenzhen, China, in July 2017.

Method: Outcomes that are especially relevant to South African botanists and mycologists are summarised from published Nomenclature and General Committee reports, as well as the published report of congress action.

Results: This short note summarises and highlights some of the decisions taken at the Nomenclature Section in China, especially those that are important for South African botanists and mycologists.

\section{Background}

The XIXth International Botanical Congress (IBC) was held at the Convention and Exhibition Center and nearby congress facilities of the Sheraton Hotel, in the modern metropolis of Shenzhen, Guangdong, southern China, during the week of 23-29 July 2017. The congress is held every six years and venues rotate depending on invitations from hosting countries and institutions. The first IBC was held in 1900 in Paris, France, almost 120 years ago. The 2017 IBC was the first where the event was held in an emerging economy. It was also the largest ever IBC with 6850 delegates from over 100 countries in attendance.

The IBC is not only the largest and, arguably, most influential global botanical conference, but also the only event where changes can be made to the rules (Articles), recommendations and other content that govern how algae, fungi and plants are formally named. Amendments to the International Code of Nomenclature for algae, fungi and plants (ICN), the most recent version of which was published after the Melbourne, Australia, IBC, that was held in 2011 (McNeill et al. 2012), are proposed at a meeting of the Nomenclature Section (NS) held during the week before the IBC proper. Nomenclatural proposals to amend the ICN have to be published in the journal Taxon, mouthpiece of the International Association for Plant Taxonomy, during the six years preceding an IBC and are then discussed and finally voted on at the NS. Proposals to conserve or reject plant names, to suppress publications and requests for other binding nomenclatural decisions are similarly published. These proposals are investigated by the relevant Permanent Nomenclature Committee and the General Committee prior to the IBC, and recommendations regarding the acceptance or rejection of each proposal are made. The NS then has the power to ratify these final recommendations from the General Committee.

\section{Nomenclature Section}

The 2017 NS was held at the Peking University HSBC Business School in Shenzhen from 17 to 21 July 2017 (Figure 1). This NS was an auspicious event as it celebrated the 150th anniversary of the publication of the first rules for naming plants that was written by Alphonse de Candolle (Lois de la nomenclature botanique adoptées par le Congrès international de botanique tenu à Paris en août 1867, published in Geneva in 1867). The 2017 meeting was attended by 155 delegates from 30 countries representing 166 institutions. South Africa was represented by the authors of this paper. Klopper carried 14 proxy votes from eight South African herbaria (including the three herbaria of the South African National Biodiversity Institute) and De Beer carried the votes of the National Collection of Fungi (PREM), representing the South African mycological community. This meant that South Africa had a total of 19 votes to cast at the NS (16 institutional votes and 3 personal votes). 


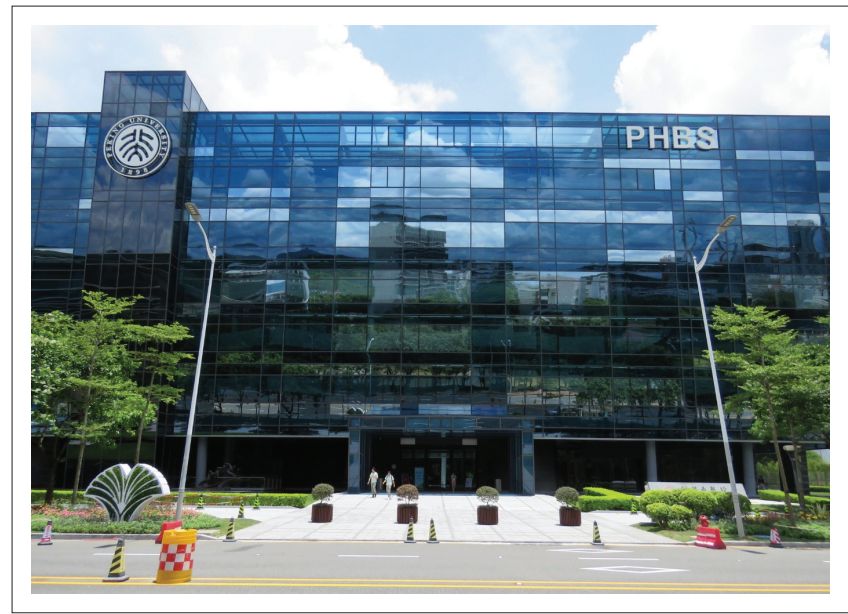

Source: Photo courtesy of G.F. Smith

The livery of the IBC is displayed in the left foreground, behind the black and yellow traffic cone.

FIGURE 1: The 2017 Nomenclature Section of the XIXth International Botanical Congress (IBC) was held at the HSBC Business School of the Peking University in Shenzhen, China, from 17 to 21 July 2017.

During 5 days of, at times, intense debate and discussion, a total of 413 nomenclature proposals (including 16 proposals introduced from the floor) to amend the ICN were dealt with (see Turland and Wiersema 2017 for a synopsis of those proposals published in Taxon). This is the largest number of proposals discussed at any NS since 1950. Of these, 120 proposals were accepted, 173 rejected, 103 referred to the Editorial Committee, 13 referred to a Special-purpose Committee and 4 were withdrawn. More detailed information on these nomenclatural proposals and their outcomes is available in the report of IBC action on nomenclature proposals (Turland et al. 2017). Decisions taken at the NS came into effect on Saturday afternoon 29 July 2017, after acceptance of the resolution from the NS by the plenary session during the closing ceremony of the IBC (Turland et al. 2017).

The most significant changes made to the ICN in Shenzhen include the following:

- Amendment of Division III that deals with the governance of the ICN (Knapp et al. 2016a, 2016b).

- Combining rules and recommendations that solely deal with fungi in a separate chapter of the ICN. This further included a decision to refer decisions on these rules that only apply to fungi to the International Mycological Congress (Hawksworth 2015; Hawksworth, May \& Redhead 2017; May 2016; May et al. 2016; Miller et al. 2017).

- Establishing a Registration Committee that will investigate the mechanisms for creating a framework for future registration of algal and plant names (Turland et al. 2017).

Five special-purpose committees were established during the 2017 NS, namely the Special-purpose Committee on Typification, the Special-purpose Committee on DNA Sequences as Types, the Special-purpose Committee on 'Lists of Available Names', the Special-purpose Committee on
Pleomorphic Fungi (Art. 59) and the Special-purpose Committee on Virtual Participation in the Nomenclature Section (Turland et al. 2017). These committees need to investigate specific issues related to the ICN and report on these by proposing possible solutions or action at the $\mathrm{XXth}$ IBC, which will be held in Brazil in 2023.

Eight reports containing 500 recommendations from the General Committee (reports 13-20; Wilson 2016a, 2016b, 2016c, 2017a, 2017b, 2017c, 2017d, 2017e) were accepted at the final session of the NS. These reports included recommendations pertaining to Art. 14 (to conserve 253 names; not to conserve 84 names), Art. 14.13 (to treat 6 lists of fungal names as conserved), Art. 56 (to reject 79 names; not to reject 15 names), Art. 34 (to suppress 13 publications), Art. 38.4 (to treat 8 names as validly published; 11 as not validly published) and Art. 53.5 (to treat 7 similar names as homonyms and 24 similar names as not homonymic) (Turland et al. 2017).

Also at the final session of the NS, officials and members of the General and Permanent Nomenclature Committees for the period leading up to the next IBC were elected. South Africa is well represented on these committees, namely on the Nomenclature Committee for Algae (John Bolton), the Nomenclature Committee for Bryophytes (Jacques van Rooy), the Nomenclature Committee for Fungi (Wilhelm de Beer), the Nomenclature Committee for Vascular Plants (Ronell Klopper and Piet Vorster), the Editorial Committee (Gideon Smith) and the Committee on Institutional Votes (Muthama Muasya) (Turland et al. 2017).

The next IBC and NS will be held in Rio de Janeiro, Brazil, in 2023 (see http:/ /www.leep.ufv.br/en-US/noticia/xx-ibc-inrio-de-janeiro-july-23th-29th-2023).

\section{Summary of decisions relevant to southern African Bryophyta and vascular plant names, and all algae and fungi names}

A summary of decisions from the 2017 NS on names that are relevant to southern African vascular plants (indigenous and naturalised) and bryophytes and all algae and fungi names are given below. For information on other decisions from the NS, the reports of the General Committee (reports 13-20; Wilson 2016a, 2016b, 2016c, 2017a, 2017b, 2017c, 2017d, 2017e) and the report of congress action from the NS (Turland et al. 2017) should be consulted. More details on these proposals and the impact of the respective committee decisions are provided in the original proposals, as published in Taxon or the report from the relevant nomenclature committee.

In the list of names that follow below, the number in brackets preceding the decision and names is the number under which the proposal was published and reported on. Abbreviations (publication titles excluded) used are: 
cons. $=$ conserved $;$ typ . cons. $=$ conserved with a conserved type; nom. cons. = conserved name; rej. = rejected name.

\section{Conserved names}

Algae: (2017) cons. Vesicularia (Müll. Hal.) Müll. Hal.; (2066) cons. Hapalosiphonaceae; (2084) cons. Rhabdosphaera; (2194) cons. Gloeobacter violaceus; (2195) cons. Gloeothece (typ. cons.); (2303) cons. Chara hispida (typ. cons.); (2382) cons. Scrippsiella; (2097) cons. Vertebraria Royle ex McCoy; (2393) cons. Catenaria Sorokin (with changed type citation); (2464) cons. Trichomonas with that spelling; (2440) cons. Lagerheimia (De Toni) Chodat.

Bryophyta: (1811) cons. Leptodontium proliferum; (2017) cons. Vesicularia (Müll. Hal.) Müll. Hal.

Vascular plants: (1357) cons. Bidens (feminine gender); (1839) cons. Leysera; (1905) cons. Ageratum conyzoides (typ. cons.); (1964) cons. Cacalia sect. Cissampelopsis (typ. cons.); (2002a) cons. Lepisorus against Belvisia, Drymotaenium and Paragramma, butnot against Lemmaphyllum and Neocheiropteris; (2016) cons. Physalis (typ. cons.); (2089) cons. Hedysarum incanum Sw.; (2095) cons. Scytophyllum Bornem.; (2129) cons. Asphodelaceae; (2138) cons. Balanites, nom. cons. (feminine gender); (2144) cons. Kumara (typ. cons.); (2238) cons. Phoenix canariensis; (2284) cons. Cliffortia filicaulis (typ. cons.); (2313) cons. Momordica lanata (typ. cons.); (2323) cons. Salsola L. (typ. cons.); (2332) cons. Sporobolus; (2335) cons. Senecio macrophyllus; (2373) cons. Casearia; (2399) cons. Aloe parvibracteata; (2403) cons. Cuscuta campestris; (2427) cons. Stellaria (typ. cons.); (2443) change author, place and date of publication of Actinidiaceae, nom. cons.

Fungi: (1828) cons. Aspicilia aquatica; (2032) cons. Pseudocyphellaria (typ. cons.); (2033) cons. Armillariella ostoyae; (2044) cons. Agaricus tabescens; (2051) cons. Talaromyces; (2052) cons. Lichen vulgatus (typ. cons.); (2069) cons. Chrysotrichaceae (with that orthographically correct spelling); (2071) cons. Lichen leucomelos with that original spelling; (2087) cons. Lecidea oederi (typ. cons.); (2100) cons. Chrysothrix, nom. cons., against additional name Alysphaeria; (2101) cons. Ganoderma camphoratum (typ. cons.); (2128) cons. Flammula (Fr.) P. Kumm. (changed typ. cons. Agaricus alnicola Fr. : Fr.); (2142) cons. Peziza ammophila Durieu \& Lév.; (2143) cons. Fuscopannaria; (2176) cons. Torula stilbospora (typ. cons.); (2196) cons. Alectoria fuscescens; (2197) cons. Hebeloma (typ. cons.); (2198) cons. Agaricus laterinus against sanctioned Agaricus fastibilis; (2210) cons. Blumeria; (2211) cons. Erysiphe arcuata; (2212) cons. Microsphaera azaleae; (2213) cons. Erysiphe buhrii; (2214) cons. Erysiphe catalpae; (2215) cons. Erysiphe celosiae; (2216) cons. Microsphaera oehrensii; (2217) cons. Erysiphe quercicola; (2218) cons. Erysiphe biocellata; (2219) cons. Erysiphe magnicellulata; (2220) cons. Golovinomyces sonchicola; (2221) cons. Erysiphe verbasci; (2222) cons. Leveillula rutae; (2223) cons. Phyllactinia alni; (2224) cons. Phyllactinia ampelopsidis; (2225) cons. Phyllactinia chubutiana; (2226) cons. Phyllactinia dalbergiae; (2227) cons. Phyllactinia gmelinae; (2228) cons. Phyllactinia populi; (2229) cons. Sphaerotheca leucotricha; (2230) cons.
Sphaerotheca euphorbiae-hirtae; (2231) cons. Sphaerotheca filipendulae; (2232) cons. Podosphaera solanacearum; (2234) cons. Helminthosporium maydis Y. Nisik. \& C. Miyake; (2274) cons. spelling of Polycaryum; (2275) cons. spelling of Polycaryum branchipodianum; (2276) cons. Erysiphaceae; (2289) cons. Morchella semilibera; (2291) cons. Geastrum (typ. cons.); (2341) cons. Lichen fuscatus Schrad. (typ. cons.); (2349) cons. Hebeloma fragilipes; (2393) cons. Catenaria Sorokin (with changed type citation); (2396) cons. Lichen muralis (typ. cons.); (2397) cons. Stereocaulon pileatum (typ. cons.). The first six lists of fungal names prepared by working groups set up under Art. 14.13 to deal en bloc with names considered to require conservation: (1) Cordyceps; (2) Diaporthales; (3) Dothideomycetes; (4) Hypocreales; (5) Leotiomycetes; (6) Trichoderma and Hypocrea.

\section{Rejected names}

Algae: (2340) rej. Jania verrucosa; (2383) rej. Goniodomataceae; (2452) rej. Fucus baillouviana.

Vascular plants: (2180) rej. Senecio lanatus; (2181) rej. Senecio populifolius; (2281) rej. Arnica coronopifolia; (2470) rej. Aloe obscura; (2471) rej. Aloe picta; (2472) rej. Aloe perfoliata var. Saponaria.

Fungi: (2050) rej. Saccharomyces sphaericus; (2288) rej. Botrytis farinosa.

\section{Suppressed works}

Vascular plants: (Unnumbered) J. de A. Pinto da Silva, Diccionario de Botanica Brasilieira (1873); (4) Steinwehr's translations in Königl. Akad. Wiss. Paris Phys. Abh. 5-9. 1754-1760; (8) E. Delpy, Tabulae Herbarii L. Pierre (18??-19??); (9-12) two publications of List of Indian Woods collected by $N$. Wallich, two publications of selections from this List ('principal trees' and 'Catalogue of woods peculiar to Goalpara'); (13) any quarto version of J.R. Forster \& G. Forster's Characteres Generum Plantarum dated; (14) any folio version of J.R. Forster \& G. Forster's Characteres Generum Plantarum dated 1775; (15) any folio version of J.R. Forster \& G. Forster's Characteres Generum Plantarum dated 1776; (19) Dochnahl, F.J. 1855-1860. Der sichere Führer in der Obstkunde vol. 1-4 [Genera and species]; (22) Miller, P. 1754. The gardeners dictionary, abridged edition 4. London (TL-2 No. 6056) [Species and infraspecific taxa]; (25) Glaziou, A.F.M. 19051913. Plantae Brasiliae centralis a Glaziou lectae. Mém. Soc. Bot. France 1(3): 1-661. (TL-2 No. 2030) [All ranks].

\section{Binding decision regarding valid publication}

Vascular plants: Considered to be validly published: Echinodorus.

\section{Binding decision regarding confusable names}

Algae: considered not confusable: Sycidium (fossil Characeae) and Sykidion (extant Chlorophyceae); Family names Sycidiaceae (order Sycidiales) and Sykidiaceae (order Sykidiales). 
Fungi and algae: considered not confusable: (25) Geisleria Nitschke (Ascomycota: Strigulaceae) and Geissleria Lange-Bert. \& Metzeltin (Bacillariophyceae: Naviculaceae).

Fungi and vascular plants: considered not confusable: (17) Otidea (Fungi: Ascomycota: Pyronemataceae) and Otidia (Geraniaceae); (20) Bertia (Ascomycota: Bertiaceae) and Bertya (Euphorbiaceae).

Vascular plants: considered not confusable: (13) Codia (Cunoniaceae) and Coddia (Rubiaceae).

\section{Binding decision regarding correct spelling}

Fungi: Correct spelling of epithet 'rhacodes' for Agaricus rhacodes to become a voted example in the ICN.

\section{Acknowledgements}

The first author (R.R.K.) is grateful for financial assistance from SANBI, the IBC Excellent Scholar Award (\#T1-17-07), and the National Research Foundation: Knowledge Interchange and Collaboration Grant (Grant no. 110152) that enabled her attendance of the NS and IBC.

\section{Competing interests}

The authors declare that they have no financial or personal relationships that may have inappropriately influenced them in writing this article.

\section{Authors' contributions}

R.R.K. conceptualised the manuscript, wrote the initial draft, reviewed the literature and summarised the decisions from the Nomenclature Section. Z.W.d.B. provided significant input into the initial draft and expanded the manuscript by providing information on mycological aspects. G.F.S. provided significant input and improved several aspects of the manuscript.

\section{References}

Hawksworth, D.L., 2015, 'Proposals to clarify and enhance the naming of fungi under the International Code of Nomenclature for algae, fungi, and plants', IMA Fungus 6, 199-205. https://doi.org/10.5598/imafungus.2015.06.01.12

Hawksworth, D.L., May, T.W. \& Redhead, S.A., 2017, 'Fungal nomenclature evolving: Changes adopted by the 19th International Botanical Congress in Shenzhen 2017 and procedures for the Fungal Nomenclature Session at the 11th International Mycological Congress in Puerto Rico 2018', IMA Fungus 8, 211-218. https://doi org/10.5598/imafungus.2017.08.02.01

Knapp, S., Turland, N.J., Barkworth, M.E., Barrie, F.R., Fortunato, R.H., Gandhi, K. et al. 2016a, '(286) Proposal to replace Division III of the International Code of Nomenclature for algae, fungi, and plants', Taxon 65, 661-664. https://doi. org/10.12705/653.41

Knapp, S., Turland, N.J., Barkworth, M.E., Barrie, F.R., Fortunato, R.H., Gandhi, K. et al., $2016 \mathrm{~b}$, 'Report of the Special Committee on By-laws for the Nomenclature Section', Taxon 65, 665-669. https://doi.org/10.12705/653.42

May, T.W., 2016, 'Report of the Special Subcommittee on Governance of the Code with Respect to Fungi', Taxon 65, 921-925. https://doi.org/10.12705/654.48

May, T.W., De Beer, Z.W., Crous, P.W., Hawksworth, D.L., Liu, X., Norvell, L.L. et al. 2016, '(362-363) proposals to amend the Code to modify its governance with respect to names of organisms treated as fungi', Taxon 65, 918-920. https://doi. respect to names of orga

McNeill, J., Barrie, F.R., Buck, W.R., Demoulin, V., Greuter, W., Hawksworth, D.L. et al. (eds.), 2012, International Code of Nomenclature for algae, fungi, and plants (Melbourne Code) adopted by the Eighteenth International Botanical Congress, Melbourne, Australia, July 2011. Koeltz Scientific Books, Königstein. [Regnum Vegetabile 154], $x x x+208$ pp.

Miller, A., Cai, L., Crous, P.W., De Beer, Z.W., Hawksworth, D.L., Hyde, K.D. et al., 2017 'Mycologists' committees strongly support changes to the governance of fungal nomenclature', IMA Fungus 8, 9-11.

Turland, N.J. \& Wiersema, J.H., 2017, 'Synopsis of proposals on nomenclature Shenzhen 2017: A review of the proposals concerning the International Code of Nomenclature for algae, fungi and plants submitted to the XIX International Botanical Congress', Taxon 66, 217-274. https://doi.org/10.12705/661.36

Turland, N.J., Wiersema, J.H., Monto, A.M., Deng, Y-F. \& Zhang, L. 2017, 'XIX International Botanical Congress: Report of congress action on nomenclature proposals', Taxon 66, 1234-1245. https://doi.org/10.12705/665.16

Wilson, K.L., 2016a, 'Report of the General Committee 13', Taxon 65, 380-381. https://doi.org/10.12705/652.17

Wilson, K.L., 2016b, 'Report of the General Committee 14', Taxon 65, 878-879. https://doi.org/10.12705/654.15

Wilson, K.L., 2016c, 'Report of the General Committee 15', Taxon 65, 1150-1151. https://doi.org/10.12705/655.14

Wilson, K.L., 2017a, 'Report of the General Committee 16', Taxon 66, 189-190. https://doi.org/10.12705/661.15

Wilson, K.L., 2017b, 'Report of the General Committee 17', Taxon 66, 478-480. https://doi.org/10.12705/662.13

Wilson, K.L., 2017c, 'Report of the General Committee 18', Taxon 66, 742-744. https:// doi.org/10.12705/663.15

Wilson, K.L., 2017d, 'Report of the General Committee 19', Taxon 66, 980. https://doi. org/10.12705/664.14

Wilson, K.L., 2017e, 'Report of the General Committee 20', Taxon 66, 981. https://doi. org/10.12705/664.15 